\title{
Revisiting Ethnic Conflict in Sri Lanka through Media and Literature
}

\author{
Archana Arul \\ Srm University, India \\ Sridhar Krishnaswami \\ Srm University, India
}

\section{Introduction}

The President of Sri Lanka, Mr. Mahinda Rajapaksa, set a defiant note on Sept. 24, 2014 in his address to the 69th session of the United Nations General Assembly. Not only did he pooh-pooh the notion of a troubled nation-state that he was presiding over, he also categorically said that 'external intervention' in the name of human rights was simply unacceptable.

"Human rights are used as a tool to implement motivated agendas with no understanding or appreciation of the complexity of issues in the countries concerned. Human rights should be recognised by all as a moral and ethical concept rather than as a political tool. External intervention without adequate consideration of the structures in a society and cultural traditions of the countries where such intervention takes place, inevitably results in destabilisation, which is very much in evidence today, in most parts of the world"', the President told the world body.

Rajapaksa then went on to a territory that both he and his cohorts have travelled several times in the past-that somehow Sri Lanka was victim of a vast illconceived conspiracy, especially in the United Nations Human Rights Council that deliberated the rapid strides made by the island nation. "Post-conflict Sri Lanka has also become an unfortunate victim of ill-conceived agendas of some in the Human Rights Council, who pay scant regard to the substantial progress achieved by Sri Lanka, in reconstruction, rehabilitation and reconciliation within a short span of 5 years" ${ }^{2}$ Furthermore, Rajapaksa addressed the obvious lack of balance and proportion in the manner in which his country is being targeted. "This is in sharp

\footnotetext{
${ }^{1}$ www.prin.gov.lk/execpres/speeches/index/sp.html

${ }^{2}$ Ibid
} 
contrast with the approach to deeply disturbing situations involving humanitarian emergencies elsewhere" ${ }^{3}$ he added.

The President also hit upon a theme that was actually opened up by the Western countries led by the United States in the wake of 9/11 to muzzle freedom in democracies and elsewhere including that of the media. "Sri Lanka remains committed to supporting all multi-lateral efforts to counter terrorism deriving from extreme ideologies impacting on people across national frontiers" ${ }^{4}$, he said. "Terrorism continues to be a grave threat to security and stability of nations across the globe. Having suffered at the hands of terrorism Sri Lanka knows well, its drastic impact on societies, communities and institutions founded on democratic traditions and ideals" ${ }^{\prime 5}$ he added.

Expectedly, even as a majority of nations were calling upon Rajapaksa and his officials to stand by the promises that have been made to the Northern and Eastern provinces, the President gave the impression that things were well in place. "With the end of terrorism in May 2009, in keeping with my responsibilities to my people, large-scale post-conflict reconstruction, rehabilitation and resettlement initiatives were implemented in the Northern and Eastern Provinces, in a relatively short period of 4 years. Most importantly, democratic structures in the North have been re-established. Elections were held to the Northern Provincial Council in September 2013, after a lapse of 28 years" ${ }^{\prime 6}$ he said.

The "transformative journey", the Sri Lankan President argued was done "in accordance with our traditional foreign policy of 'friendship towards all and enmity towards none'. We hope that the international community will reciprocate and assist Sri Lanka in her domestic process of reconciliation and economic development without exerting undue pressure on us" ${ }^{, 7}$ he told the August gathering while stressing that his government "remains committed to its objective of pursuing the processes of reconciliation, and nation building, undeterred by illmotivated criticism"

Rajapaksa's defensive posturing is not without good reasons for after all he started off his second term in 2010 with the hope that the past will soon have to be forgotten. In an interview with The Hindu in November 2010, the President of Sri Lanka maintained

\footnotetext{
${ }^{3}$ Ibid

${ }^{4}$ Ibid

${ }^{5}$ Ibid

${ }^{6}$ Ibid

${ }^{7}$ Ibid

${ }^{8}$ Ibid
} 
To the international community, my message is they must understand our position. We defeated terrorists, not freedom fighters. The whole world is facing this problem. So they must realise what we have achieved and help to develop the country, develop the North-East. They must help us not to widen the gap between the communities but to bring them closer. The past is past; you don't dig into the wounds. We must think positively, not negatively" ${ }^{\text {"9 }}$, Rajapaksa maintained. And as is his wont, the President summarily rejected any allegations of human rights violations.

"I understand the plight of the NGOs. They have to say something. Whatever we do, finally we won't be able to change their views - we might be able to change the views of a few of them but not all of them. They must realise that if you talk about other countries, conflicts are there, human rights issues are there. You can see the difference. For example, when all the 300,000 came this side and we started building some villages and kept them there, they said we were keeping them in 'concentration camps'! You went there at that time, you could see for yourself whether they were concentration camps. When we re-settled them, they said 'no permanent houses.' Within six months, we have to build permanent houses. But without de-mining, how can we go and settle them? If we had settled them, they would have said we did this purposely to kill these people..."10 the President said alluding to the fact that some of the NGOs have involved themselves in local politics.

Interestingly some four years down the line, Rajapaksa, had the same line to offer to The Hindu again in the course of an exclusive interview-more of the same pretension that everything was honky dory in that island nation and once again drawing the distinction between terrorists and freedom fighters. "We have already implemented 35 proposals of the LLRC (Lessons Learnt and Reconciliation Commission) and more are to be implemented. Some of them deal with issues like land, which can't be done overnight. At the UNHRC session in progress right now; your ambassador admitted there have been thousands of cases of disappearances during the war years. We have already appointed a Disappearances Commission in Sri Lanka, and about 20,000 cases have appeared before the commission. The cases are from both the North (Tamil-dominated areas) as well as from the armed forces. The report is still not out, but from what I understand, the majority of the cases are where the LTTE was responsible for the disappearances ${ }^{11}$ " Rajapaksa said.

\footnotetext{
${ }^{9}$ Interview with N. Ram of The Hindu, Nov 23, 2010

${ }^{10}$ Ibid

${ }^{11}$ Interview with Suhasini Haider - Diplomatic Editor The Hindu, Sep 11, 2014
} 
The President would not subscribe to the notion that the war had been won but the government is yet to win the peace. "If you go to the north and east you will see the real situation. We can't change the mindset of the older politicians, the ones who were once entrenched with the LTTE, but younger people feel differently today. We held provincial council elections there last year, knowing very well that we would lose. There is a new freedom of movement after the war. People from the north are freely travelling to the south in Sri Lanka, those from the south feel comfortable travelling to the north" ${ }^{\prime 2}$ Rajapaksa said rejecting the notion that there is still a large military presence in the North and the East.

"Since the war ended in 2009, the presence of the military has been reduced by 90 per cent. I am trying to move them to other areas...but how much further can I go? I have to find space for my Army in Sri Lanka itself...I can't send them to be housed in India or some other country, can I?"13 The President said going on to also reject the argument that there had been the colonization of the Tamil areas with non-Tamils settling in there as a deliberate state policy.

"I deny that categorically. There has been no demolition of Tamil monuments. There is no colonisation. But in Sri Lanka, any citizen can live in any part of the country - whether the person is Tamil, Sinhalese or Muslim" ${ }^{, 14}$ he said.

And just as he was defiant at the United Nations General Assembly session, Rajapaksa rejected any notion of an outside agency conducting an enquiry in Sri Lanka and cleverly raised the issue of Kashmir to drive home the concept of national sovereignty. "We want a local enquiry here to find out what happened to them. Obviously many are missing in the war, both from the civilians and the Army. But we reject this UN commission, and how it was formed. From the beginning, the statements by the (former) UNHRC Commissioner (Navi Pillay) were biased. We invited her here. She told us one thing and said another thing after returning. But we have nothing to hide, so if the new Human Rights commissioner wishes to come, we would accept his request ${ }^{\prime \prime 15}$.

"Our government is speaking of local investigations, but we won't allow them to internationalise it. The next time if they will say that there must be an international enquiry into Kashmir, what would be our position? Would we support such a thing? No! Whether it is against India or Sri Lanka, we will not allow an external inquiry. It is all politics" ${ }^{\prime 16}$ the Sri Lankan leader said going on to insist that the

\footnotetext{
${ }^{12} \mathrm{Ibid}$

${ }^{13}$ Ibid

${ }^{14}$ Ibid

${ }^{15} \mathrm{Ibid}$

${ }^{16} \mathrm{Ibid}$
} 
killing of the 12-year old son of the LTTE Supremo was not done by the Lankan military. "We are investigating it still...I don't believe that it was (carried out by the military). But if it is true, I must know. That is why we are enquiring. In a war, when both sides are fighting, how can you say who shot at him?"17

The defiance and defensive posturing are not without good reasons. In the last five years scores of reports have surfaced condemning Colombo on what had transpired in the last months of the brutal civil war that lasted nearly three decades. Estimates vary, but it is generally said that between January and May 2009- that is the closing stages of the war-anywhere between 40,000 to 70,000 civilians were put to death indiscriminately. "Colombo has maintained that it was the cadres of the Liberation Tigers of Tamil Eelam holding on to civilians as bargaining chips for international mediation or gunning them down mercilessly, but independent observers and organizations have laid the blame squarely on the Sri Lankan government and refuse to absolve it of war crimes and genocide even if the LTTE had played a role" $" 18$.

The defiance and obduracy of the Sri Lankan President, his military, diplomatic and civilian officials can almost be pegged to the "No Fire Zone: Killing Fields of Sri Lanka", a documentary that is seen as not only detailed and meticulous in his making but also a spine chilling drama played out by people who lived through those traumatic 138 days, the last moments of the brutal conflict. As the producers put in a synopsis, the film documented the 'day to day horror', seen as nothing less than direct evidence of war crimes which included summary executions, torture and sexual violence. The argument has been made that "while the world looked away in the first few months of 2009, between 40,000 and 70,000 civilians were 'massacred' mostly by the Sri Lankan government, 'though the Tamil Tigers also stand accused of war crimes', in the Tigers' de facto capital of Killinoichi. The footage also drives home a critical point that Rajapaksa and his team have been denying day in and day out - the repression and the ethnic restructuring of the Tamil areas in the North. "Without truth there can be no justice in Sri Lanka. And without justice there can be no peace" 19 , the commentary of the synopsis says making the point that the film is part of that 'truth telling'.

The slaughter in the No Fire Zone awakened the conscience of many in the international community even as the documentary makers and Channel 4, the reputed British television station along with its editors were under intense pressure from the official Sri Lankan government. "But the obvious had been stated by the

\footnotetext{
${ }^{17}$ Ibid

${ }^{18}$ Reports of the (UN) Secretary General's panel of Experts on Sri Lanka, March 31, 2011

${ }^{19}$ www.imbd.com
} 
time of the Commonwealth Summit in 2013 was hosted by Colombo with all the fanfare even if the Heads of Government of India and Canada had stayed away and for different reasons" ${ }^{\prime 2}$.

Writing in The Guardian, Callum Macrae who was literally the face behind the powerful docudrama says, "No Fire Zone shows the relentless horror of those final weeks. These are images so shocking that they changed votes when we showed a cut of the film at the UN Human Rights Council in March. In the last few days of the war, in May 2009, the massacre of the civilians was followed by another series of war crimes. Victorious government troops systematically executed bound, blindfolded prisoners. Women fighters were stripped, sexually assaulted, blindfolded, and shot in the head. In one incident the 12-year-old son of the Tigers' leader is seen first in captivity, eating a snack. Two hours later he lies dead, having been shot, five times, at point-blank range. These events were recorded by the perpetrators on mobile phones as grotesque war trophies" ${ }^{21}$.

"These things happened and they must not be ignored. Because although the war in Sri Lanka is over, the repression continues - indeed it is escalating. The Tamils in the north are denied basic human rights; places of worship and of cultural or religious significance to the Tamils are being destroyed; rape is routinely used as a weapon of repression; and the ethnic makeup of the region is being re-engineered by a Sinhala plantation of fishermen and farmers. Throughout the country, government critics are being attacked, silenced, and are disappearing. The judiciary is under attack - the chief justice impeached and independently minded judges marginalized" ${ }^{\prime 2}$ he added.

The outrage sparked by The Killing Fields of Sri Lanka did not stop with Channel 4. It served as a backdrop to a host of organizations and respected world leaders to step up the ante and pressure the Rajapaksa government into allowing an international team of investigators to get to the bottom of what really happened in those five months of 2009. In fact the horrors of what went on in the final weeks and months of the showdown did not begin merely in 2013. In 2011 Channel 4 exposed "damning evidence of atrocities including a forensic examination of a systematic execution of naked and bound LTTE prisoners including the gruesome video footage of a 12 year old brutally killed" ${ }^{\prime 23}$.

"Selective memory is a defense mechanism with which we are all familiar. For governments and international organizations, as with individuals, moral failure is

\footnotetext{
${ }^{20}$ BBC News Asia, Nov 15, 2013; Australian Business Times, Nov 18, 2013

${ }^{21}$ Callum Macrae's column in The Guardian, Sep 3, 2014

${ }^{22}$ Ibid

${ }^{23}$ Channel 4,2011
} 
easier to live with if we can pretend that it never happened. But mass atrocity crimes did happen in Sri Lanka, there was moral default all around, and if we do not learn from this past, we will indeed be condemned to repeat it ${ }^{\text {"24 }}$ says Garreth Evans, former Foreign Minister of Australia and President of the International Crisis Group.

"One of the worst atrocity crime stories of recent decades has barely registered in the world's collective conscience. We remember and acknowledge the shame of Cambodia, Rwanda, Bosnia, and Darfur. We agonize about the failure to halt the atrocities being committed almost daily in Syria. But, at least until now, the world has paid almost no attention to war crimes and crimes against humanity comparable in their savagery to any of these: the killing fields of Sri Lanka in 2009.Three years ago, in the bloody endgame of the Sri Lankan government's war against the separatist Liberation Tigers of Tamil Eelam, some 300,000 civilians became trapped between the advancing army and the last LTTE fighters in what has been called "the cage" - a tiny strip of land, not much larger than New York City's Central Park, between sea and lagoon in the northeast of the country"25

"The lack of outrage mainly reflects the Sri Lankan government's success in embedding in the minds of policymakers and publics an alternative narrative that had extraordinary worldwide resonance in the aftermath of the terrorist attacks of September 11, 2001. What occurred in the cage, according to this narrative, was the long-overdue defeat, by wholly necessary and defensible means, of a murderous terrorist insurrection that had threatened the country's very existence. The other key reason behind the world's silence is that the Sri Lankan government was relentless in banning independent observers - media, NGOs, or diplomats from witnessing or reporting on its actions. And this problem was compounded by the timidity of in-country United Nations officials in communicating such information as they had"26, he added.

But Evans conveyed an important message: "President Mahinda Rajapaksa's government claimed throughout, and still does, that it maintained a "zero civilian casualties" policy. Officials argued that no heavy artillery fire was ever directed at civilians or hospitals, that any collateral injury to civilians was minimal, and that they fully respected international law, including the proscription against execution of captured prisoners. But that narrative is now being picked apart in a series of recent publications, notably the report last year of a UN Panel of Experts, and in

24 http://www.project-syndicate.org/commentary/accountability-for-sri-lanka-s-official-killers-bygareth-evans\#k4KHRG7FcaYed8HA.99

${ }^{25}$ Ibid

${ }^{26} \mathrm{Ibid}$ 
two new books: UN official Gordon Weiss's relentlessly analytical The Cage: The Fight for Sri Lanka and the Last Days of the Tamil Tigers, and BBC journalist Frances Harrison's harrowingly anecdotal Still Counting the Dead: Survivors of Sri Lanka's Hidden War"'27.

"Nobody underplays the LTTE's contribution to the 2009 savagery; but, with the Tigers' leaders all dead, international attention should now be focused overwhelmingly on holding the government accountable for its failure to accept its responsibility to protect its own people. For far too long, Rajapaska's government has been evading accountability with an endless stream of diversionary maneuvers (usually involving committees of inquiry intended to lead nowhere, and duly complying), denial of physical access, outright dissimulation, and relentless verbal intimidation of anyone daring to question it ${ }^{28}$ he says in his commentary.

In fact even as early as 2011, Louise Arbour, another President of the International Crisis Group drew the distinction between South Africa's Truth and Reconciliation Commission to Sri Lanka's LLRC stressing that South Africa knew better that a country cannot begin to overcome decades of internal conflict without a sustained effort at revealing the truth of the past together with a committed push for reconciliation. "If only Sri Lanka could learn that lesson" 29 .

"Rather than starting on the slow, painful path towards a more democratic and equal society, however, the post-war policies of President Mahinda Rajapaksa and his powerful brothers have further undermined the country's damaged political institutions and deepened the ethnic divide. Progress toward reconciliation was always going to be difficult" ${ }^{\prime 30}$ she said going on to make the point that instead of meeting the challenges " the government has increasingly cut minorities out of decisions on their economic and political futures, clinging to its claim that the war was about "terrorism" and not an ethnic conflict. It has controlled narratives both within and outside the country, reacting furiously to any challenge to the official version" 31 .

Arbour was equally critical of the Sri Lankan Tamil diaspora. "The unwillingness of much of the million-strong Sri Lankan Tamil diaspora to recognise the brutality of the LTTE and its share of responsibility for a largely broken Tamil society has only strengthened the government's hand. The Rajapaksas tell a different story, claiming to be pursuing reconciliation and accountability, in part through the

\footnotetext{
${ }^{27}$ Ibid

${ }^{28}$ Ibid

${ }^{29} \mathrm{Ibid}$

${ }^{30}$ Louise Arbor president International Crisis group in Sunday Independent, July 22, 2011

${ }^{31}$ Ibid
} 
Lessons Learnt and Reconciliation Commission (LLRC) set up by the president over a year ago. But this process is deeply flawed, as a UN panel of experts, including South Africa's own Yasmin Sooka recently determined. Indeed the panel's report specifically addressed the government's claim that it had drawn on South Africa's Truth and Reconciliation Commission (TRC), finding that the LLRC falls far short of that important precedent." ${ }^{32}$

“As Sri Lanka's long history of failed and ignored presidential inquiries demonstrates, these mechanisms are ultimately powerless. The country's post-war course will not change unless the Rajapaksas decide it has to. So far, they have shown no interest in doing anything that would diverge from the Sinhalese nationalist vision they have embraced fully, as both means to stay in power and end in itself. Instead, they continue to repress the media and political opponents, while manipulating elections and silencing civil society. Constitutional reforms strongarmed through parliament in 2010 have removed presidential term limits and solidified the president's power over the attorney general, judiciary and various "independent" commissions" ${ }^{33}$ Arbour maintained.

"The government has also defiantly rejected the growing body of evidence supporting allegations of war crimes and crimes against humanity by both sides in the final stages of the war, including the UN panel's report and a recent television documentary "Sri Lanka's Killing Fields", first aired by the UK's Channel 4 on June 14, but since shown internationally and online. Sri Lankan officials continue to deny that government forces did anything wrong, but as more and more evidence emerges, their attempts to white wash the crimes are looking ever more absurd. The frustration engendered by the government's refusal to take any responsibility for alleged crimes, combined with the rest of its post-war agenda, are increasing the risks of renewed violence" ${ }^{34}$ Arbour said while calling on the international community to push for a "fundamental change of course".

The muzzling of the media in the run up to the Commonwealth Meeting in 2013 and the ire of the Sri Lankan government against Channel 4 was reflected in a 222 page book distributed to journalists entitled Corrupted Journalism: Channel 4 and Sri Lanka, a contention that was immediately taken apart by Ben de Pear, News Editor of the Channel. In his welcome page to CHOGM, President Rajapaksa states this explicitly: "Sri Lanka is committed to upholding Commonwealth values of

\footnotetext{
${ }^{32}$ Ibid

${ }^{33}$ Ibid

${ }^{34}$ Ibid
} 
democracy, rule of law and good governance" ${ }^{35}$. His government's appalling human rights record, the lack of accountability for past and present crimes and the trampling of the freedom of speech make his words a mockery.

"Our reporting and that of many others over the past five years has proved that again and again. Our story of reporting in Sri Lanka is totally insignificant compared to that of the countless thousands who have been killed, tortured or disappeared but for the record, and to answer the allegations in the book here it is, and the links to the work we have done and the films commissioned by Channel 4 directed by Callum Macrae. On 8 May 2009, after reporting allegations of the multiple rapes of displaced Tamil women by Sri Lankan soldiers in "rehabilitation" camps, our Asia news team was deported from Sri Lanka. At the time they had been trying, repeatedly, to gain access to the area in the north east which the Sri Lankan army had named the "No Fire Zone" ${ }^{36}$ de Pear said in his spirited rebuttal to the charges.

"Our journalism and the authenticity of the videos was similarly scrutinised by the United Nations. Employing two of the world's foremost video and audio experts, a thorough three month investigation and report by the UN found the videos to be authentic. Another report commissioned by the UN Secretary General Ban Ki Moon further verified the findings, and demanded an investigation into the end of the war...There were so many videos, so much evidence we couldn't run it all, and because of our broadcast time at $7 \mathrm{pm}$, we couldn't show them because they were so graphic. So Channel 4 commissioned films out of them. These became strong testimony viewed by the UN and human rights organisations as evidence of some of the worst war crimes of the century"37 de Pear argued.

Prime Minister David Cameroon on the No Fire Zone said, "No right-thinking person can regret the end of the terrorist campaign waged by the Tamil Tigers nor ignore the terrible crimes they committed. But that wrong does not change the fact that this documentary raises very serious questions that the Sri Lankan government must answer about what it did to protect innocent civilians. Questions that strengthen the case for an independent investigation. Questions that need answers if Sri Lanka is to build the truly peaceful and inclusive future its people deserve." ${ }^{\prime 38}$

"Since the films, and four years since the end of the war, the images still keep emerging of what happened in that tiny strip of land amongst those thousands of

\footnotetext{
${ }^{35}$ Ben de Pear, Channel 4 commentary,"Sri Lanka, 'Corrupted Journalism and Channel 4', Nov 9, 2013

${ }^{36} \mathrm{Ibid}$

${ }^{37}$ Ibid

${ }^{38}$ Ibid
} 
people and then prisoners. The Sri Lankan government's position that these videos are fake does not stand up to scrutiny. Our journalism has been subjected to incredible scrutiny and only the Sri Lankans have found it wanting. In a post war Sri Lanka, journalists still disappear, or are threatened by government ministers to have their legs broken in public, people are picked up by the white vans and never seen again, and according to Human Rights Watch sexual violence by the army in the now occupied north is out of control" ${ }^{39}$ de Pear notes.

The Rajapaksa government was further floored and is still smarting under a highly damaging report prepared by Australia's International Crimes Evidence Project in February 2014 entitled Island of Impunity that laid down thread bare the final stages of the conflict of how the last days turned into a living hellhole for those trapped in the so-called cage. The report has been placed before Australia's Parliament. Amongst the key findings:

- Although violations were committed by both sides, evidentiary material indicates that members of the Sri Lankan Security Forces perpetrated the vast majority of alleged crimes during the investigation period.

- Flagrant and reckless disregard for the laws of war strongly suggesting there was intent to commit those crimes... Sri Lankan security forces conducted indiscriminate artillery bombardments of areas known as civilian concentrations, also striking hospitals and humanitarian sites.

- Both parties were involved in widespread torture, sexual violence and enforced disappearances. Today these are in part perpetrated by the Sri Lankan Security Forces on the civilian population.

- The Sri Lankan government may have sought systematically to exhume and destroy evidence of mass civilian deaths.

- The ICEP has questioned why the Sri Lankan military established three successive No Fire Zones in North East Sri Lanka where the LTTE were already conducting operations and in the process substantially increasing the risk of heavy civilian casualties.

- The attacks on civilians suggest that the use of military force was "manifestly" disproportionate to any anticipated military advantage. Even if there was the presence of LTTE cadres, the Sri Lankan Forces did not take adequate precautions to protect civilians from attack... such acts could also amount to the war crime of attacking a military objective that causes excessive incidental civilian losses.

- Photographs, video footage and eye witness accounts, helped locate Tamil news reader Isaipriya alive, unarmed and in Sri Lankan force's custody on the 
same day as other photographs and footage showed her lying dead on the ground, partially naked with blood on her face and left breast.

- The evidentiary material of the ICEP showed the 12 year old son of the LTTE Supremo was dead less than two hours after being taken into custody by Sri Lankan forces, killed by five bullets shot at close range. ${ }^{40}$

"More than four years since the end of the Sri Lankan civil war, the Sri Lankan Government has failed to address serious and credible alleged violations of international law. The Sri Lankan Government has not complied with the UN Human Rights Council's March 2012 resolution on reconciliation and accountability. There is strong concern about the independence of Sri Lanka's judiciary and the inadequacy of other checks on executive and military power. Accordingly, there remains serious doubt that the Sri Lankan Government will establish a credible investigation into allegations of war crimes, crimes against humanity and breaches of international human rights law and IHL" ${ }^{41}$ the reports says.

"An independent and comprehensive international investigation is needed into these alleged violations of international law. Failure to do so can only damage the prospects of meaningful and enduring reconciliation in Sri Lanka. The absence of such an investigation will also ensure the ongoing impunity of those on both sides of the conflict who have committed violations of IHL and international human rights law, thereby emboldening those who may continue to abuse the civilian population" the report maintains in an ominous fashion." ${ }^{42}$

\section{Conclusion}

No matter where the government of Sri Lanka turns in, it is feeling the weight and pressure of the international community to come away clean on its track record relating to the closing stages of the ethnic war in 2009. The argument that the LTTE was "also" involved in crimes does not mask the fact that nation-states are duty bound to protect their civilians especially when a group opposing the state has already been designated as a terrorist outfit. By the same token the Rajapaksa government has had this itch to brand many or all of its detractors, who are either sympathetic to the LTTE or supposedly on the LTTE payroll, an accusation that hardly merits any enquiry given the source. Worse still, domestic and foreign

\footnotetext{
${ }^{40}$ Executive Summary of the Full Report, Taken from 1.1 through 1.33, International Crimes Evidence Project - Sri Lanka of Impunity, Investigation into International Crimes in the Final Stages of the Sri Lanka war. Copyright Public Interest Advocacy Centre, Sydney, Australia, Feb 2014

${ }^{41}$ Ibid, Executive Summary 1.45

${ }^{42}$ Ibid, Executive summary 1.46
} 
journalists who had questioned the intent and intentions of the government have been threatened, harassed or in some instances even done away with. This reiterates that Colombo has little to contribute by way of countering the "message" and felt comfortable in going after the "messenger".

There have been at least two ways in which Colombo has sought to dismiss charges of gross human rights violations: first in the typical "right of reply" trying to discredit what has been put out. For instance, as a rebuttal to Callum Macrae's No Fire Zone , the Sri Lankan High Commission in London on March 7, 2014, had this to say: "Your latest attempt to denigrate Sri Lanka is a continuation of your pernicious campaign that has already been exposed in the book Corrupted Journalism Channel 4 and Sri Lanka. Your allegations are such unmitigated and unsubstantiated rubbish that you make even gutter journalism appear to be Pulitzer Prize-winning professionalism. What makes your journalism doubly dubious and obnoxiously unbalanced is that you expect us to comment on footage which, in fairness, we have not even been given the opportunity of seeing or hearing." ${ }^{43}$

"It is a pity that your continuing propagandist vendetta against Sri Lanka only continues to undermine the process of reconciliation and healing that we have undertaken after a near three-decade long terrorist war.It is certainly not going to help those in Sri Lanka you pretend you are helping but who only wish to live in peace without external meddling and posturing. Your crude journalism exposes both Callum and your calumny." 44

Macrae further exposes the extent to which Sri Lanka would officially go in threatening and harassing a foreign correspondent. In Australia to promote his film, Macrae had the following to say: "a senior Sri Lankan diplomat there, Bandula Jayasakara (formerly Rajapaksa's chief media adviser), tweeted a message to me. He said he would "make sure you don't get a visa" and accused me of being "hired by [Tiger] terrorists as a full time propagandist for the bloodthirsty terror group overseas". Additionally, when I recently told a Sri Lankan newspaper that I intended to visit the country to cover CHOGM I received a series of death threats, all published online. You are welcome to come to Sri Lanka, said one, "only to go back in a coffin". And another said: "Callum Macrae - do not come to Sri Lanka. You will be abducted in a white van, and sent to meet Lasantha Wikremasinghe [sic].".45

\footnotetext{
${ }^{43}$ Callum Macrae, Channel 4 March 9, 2014 http://www.channel4.com/news/sri-lanka-video-warsexual-violation-tamil-execution-macrae

${ }^{44}$ Callum Macrae The Guardian, Sept 3, 2013
} 
"White vans are recognised as an instrument of terror in Sri Lanka, regularly used to abduct government critics. Lasantha Wickrematunge was the editor and founder of the Sunday Leader - a respected newspaper critical of the Rajapaksa regime. He was shot and killed by unknown assassins in January 2009, just a few days after criticising the government's conduct of the war, ${ }^{36}$

The more worrisome aspect of Sri Lanka is neither obduracy nor denial of what took place in the closing stages of the brutal ethnic conflict; it is in the symbol of triumphalism masquerading once again the ugly faces of racism that tore apart the Island nation. Even as the regime in Colombo is being called up for accountability in the fashion in which it went about crushing the LTTE cadres and innocent Tamilians suspected of being pro-LTTE sympathizers or whose only "mistake" was to be at the wrong place at the wrong time, the Rajapaksa government is being held accountable to a raft of planned attacks against the Muslim minorities who for ages had been neither here nor there. The targeting of Muslims ostensibly for religious and cultural reasons or in a perception that they are about to change the heritage of the Sinhalese has set in motion a destructive path ultra nationalist, right wing and other groups sitting on the fringes of extremism

It also brings to the fore an aspect of a tortured past of the troubled island nation as reflected in the writings of Sri Lankan novelists, some of whom are of Tamil origin but had to leave the country, by choice or by force. Skimming through what has been written in the 1990s throws light on what is being said today by United Nations Resolutions, Organisations promoting and protecting human rights as well as the rhetoric of the political establishments in Sri Lanka, India and elsewhere. The bottom line is not too hard to see: that what is being advised of Sri Lanka today has already been said decades ago, but only in a different language. And what is happening in Sri Lanka today is nothing but a re-visit to the past and with a powerful message.

"Sri Lanka was a country pretending that it had been suddenly scrubbed clean of violence" ${ }^{47}$ says Samanth Subramanian in his latest novel 'This Divided Island Stories From The Sri Lankan War'. The book, a rich mixture of reflections and historical anecdotes is divided into four broad sections Terror, The North, The Faith, End Games-- each with its own unique and striking significance laced with a racy style of writing that would cause envy amongst even the seasoned scribes in South Asia and the world. Set in the genre of a travelogue, the stories recorded in the book leaves disturbing images of the Sri Lankan war and a welcome addition to

\footnotetext{
${ }^{46}$ Ibid

${ }^{47}$ Samanth Subramanian, This Divided Island: Stories From The Sri Lankan War
} 
the literature and not just in the realm of diasporic contribution but also from the perspective of the media.

The temptation will be in some quarters to dismiss the seminal work as some sort of an apology for the Tamils. To fall for this easy line of thinking would in quite unsophisticated for Subramanian also records the fashion in which the Liberation Tigers of the Tamil Eelam went about its business in the name of achieving the stated objectives. 'Ten years, I calculate to myself. That was long it had taken for the Tigers to go from killing out of perceived necessity to killing for sport.' In an anecdote later, we are told of how grief struck and terrorized were the civilian Tamils who were clearly displeased with some of the tactics and policies of the LTTE Supremo.

Put in a current context Subramanian's work is not just yet another "book" on a period of history that many would like to think did not happen or pretend that it did not take place. To the apologists of the powers-that-be in Colombo that "nothing happened" or what did happen could be swept under the carpet because the "opposition" also did the same will not wash for the simple reason that nation states are held to a higher bar in the process of governance. And invoking the concept of national sovereignty and trying to drum up support on this point from dictatorships around the world does not speak too highly of an Island Nation that has its roots in democracy and human rights.

Sri Lanka needs to get to the bottom line-is genuine national reconciliation possible without coming to terms with the excesses in the last phase of the war? And that is the genuine issue that needs to be addressed. Brushing aside the calls of the international community, throwing up the bogey of a return of terror or going about intimidating yet another community in the hope of further nurturing the triumpantalism bodes ill not just for Sri Lanka and India but for South Asia and the world at large.

And the same holds for drumming up support for the concept of national sovereignty or in subtly reminding India of the consequences of having outside intervention in Kashmir. President Rajapaksa and his ilk ought to keep in mind that Kashmir and what took place in the North and East of Sri Lanka in 2009 are two different things: the first having to do with a political dispute that involves more than just India and Pakistan; and the latter having to do with allegations of orchestrated killing, pogrom and executions that has left civil society around the world stunned.

In fact President Rajapaksa would well to remember what Official China-one of Sri Lanka's recent benefactors - had to say at the end of the CHOGM meeting in 
2013. "...human rights conditions should be improved by the governments of countries concerned through their efforts and constructive help should also be offered by the international community ${ }^{48,}$ In fact it is also being pointed that Japan's Special Envoy for Peace-Building, Rehabilitation and Reconciliation in Sri Lanka Yashushi Akashi, who previously had positive things to say about the Rajapaksa government for its efforts changed his mind after a visit in December 2013 - that the Sri Lankans were anxiously " waiting for action and not just sound and fury." ${ }^{49}$

Calling upon Colombo to eliminate the credibility gap with respect to perception and reality pertaining to the proposals pout forth for national reconciliation, Akashi, a veteran who was the civilian in charge of the United Nations Transitional Authority for Cambodia (UNTAC) in the 1990s, said "There is a certain amount of impatience and frustration on these matters and there is a notion that the Sri Lankan Government has taken too much time appointing commissions and then shelving their reports without taking any action. I hope the government of Sri Lanka is reflecting upon these past repetitions. I think time has come for action and I hope that kind action is needed, the implementation of the LLRC report is a good testing case of real action, it's the people in Sri Lanka not those in other countries are anxiously waiting for action and not just sound and fury." ${ }^{, 50}$

\section{References and notes:}

Arbor, Louise, Sunday Independent, July 22, 2011

BBC News Asia, Nov 15, 2013; Australian Business Times, Nov 18, 2013

Daily Mirror, Sri Lanka, Dec 13, 2013

De Pear , Ben, Channel 4 commentary, "Sri Lanka, 'Corrupted Journalism and Channel 4', Nov 9, 2013

Macrae, Callum, The Guardian, Sept 3, 2013

Macrae, Callum, Channel 4 March 9, 2014

Reports of the (UN) Secy General's panel of Experts on Sri Lanka, March 31, 2011

Subramanian, Samanth, This Divided Island: Stories From The Sri Lankan War

Sultana. Gulbin, On Post-CHOGM Dilemmas of Rajapaksa , Comment in Institute of

Defense Studies and Analysis, Jan 15, 2014

The Hindu, Interview with N. Ram, Nov 23, 2010

The Hindu, Interview with Suhasini Haider, Sep 11, 2014

\footnotetext{
${ }^{48}$ Gulbin Sultana on Post-CHOGM Dilemmas of Rajapaksa, Comment in Institute of Defence Studies and Analysis, Jan 15, 2014

${ }^{49}$ Daily Mirror, Sri Lanka, Dec 13, 2013

${ }^{50} \mathrm{Ibid}$
} 


\title{
Summary
}

\section{Revisiting Ethnic Conflict in Sri Lanka through Media and Literature}

\author{
Archana Arul \\ Srm University,India \\ Sridhar Krishnaswami \\ Srm University, India
}

The brutal twenty six year old ethnic strife in Sri Lanka came to a painful end in May 2009. Five years down the line questions are still being raised on what precisely it was that tore apart the Island Nation - a crisis of identity, lack of assimilation of the so-called migrants, majoritarianism or simply a nation so engrossed in cultural supremacy that it could not care for its minorities? Worse of all, the political leadership in Sri Lanka seems to be in a denial concerning what took place towards the end of the conflict, hence making it appear as one of the classic debates between 'terrorists' and 'freedom fighters'. This paper will make the case that media exposure on the issue of genuine national reconciliation of NGOs and disasporic literature has only toughened the stance of the powers-that-be in that Island Nation making genuine national reconciliation a distant dream.

Key words: Assimilation, Cultural Supremacy, Ethnic Conflict, Identity, National Reconciliation 